\title{
Globalization and the global manual of Islamic education
}

\author{
Shehu Yusufu Birnin Tudu \\ Department of Islamic Studies, Adamu Augie College of Education, Argungu, Nigeria
}

\begin{abstract}
The global world does not exist on it own, nor the events in the globe left without a guide. For machinery to operate successfully there is the need for strict adherence to its operation manual. The source of Islamic education provides man with complete code of life as guiding principles covering all aspects of the global life. The paper discuss Qur'an the Devine rules from the global Creator to the universal creatures, the bases and guide for successful universal or global operation and development.
\end{abstract}

Keywords: Islamic education; global life; globalization

\section{INTRODUCTION}

The contemporary globalization has ushered in new developments under different epithets and information and communication technology (ICT) is one of the wonders of our contemporary world, which has been turned into a global village. The influx of information and communication technology is responsible for the e-everything (e-learning, e-banking, email, e-library, e-registration etc). The dissemination of information throughout the universe within the spate of time is a major achievement of man (globalization). This is facilitated by the varieties of opportunity created by the information and communication technology, the study, design, development, support or management of computer-based information systems particularly software applications and computer hardware (Badmos. O. Y. Correlate of Islam, p. 225). Through these technologies the happening in one part of the globe is quickly transmitted to other parts. These technologies are used in all spheres of life.

As far as globalization means development, it is one of the aims of Islamic education. Both Islamic education and information and communication technologies left no aspects of man's life untouched. However the former guides the development of the later.

Education in Islam involves the over-all development of man, his intellect, character, personality and relationship between man and his creator, between man and his natural environment, between man and fellow human being.

Islam has attached great importance to education. Education is a means through which prophet Adam (A.S) become superior over the Angels. Education is the best agent of development. Development of any nation depends on the level of education possessed by that nation. This paper discusses Islamic education as a manual for global operation and development. 


\section{AIMS AND SIGNIFICANCE OF ISLAMIC EDUCATION}

Islamic education is geared towards realization of mundane and divine objectives of human existence in this world. In other words the primary aims of Islamic education is to help man understand this world and the next, works towards advancement in both worlds. Islamic education aims at raising the status of man and promote mankind to higher status socially, spiritually, and technologically.

It aims at making man realize his relationship with his creator Lord and sustainer of the world. Islamic education is perfect and unique curricula (manual), a solid foundation for development and civilization in the life of mankind right from the time of prophet Adam (A. S.) to the present day generation.

The perfect universal curricula of Islamic education, is designed by the ultimate creator of the universe. He knows the universe better than the inhabitants of the universe.

He sent His first technologist and all round teacher of this generation, and instructed him in the first instance to read;

"Read in the name of your Lord who created, who created man from cloth,... who taught by the use of pen. He taught man what he knew not", (Qur'an, 96:1-5).

Allah (SWT) the global creator, bestowed knowledge and wisdom to whom He pleases and make him to excel in all ramifications.

The Qur'an says:

"He grants wisdom to whom He pleased, and he to whom wisdom is granted received Indeed a benefit over flowing, but will grasp the message but men of understanding", (Qur'an, 2: 269).

Islamic education has it primary source from the Qur'an, it helps man in acquiring wisdom. It is comprehensive because it trains emotional and intellectual faculties simultaneously. Man is expected to learn through experiments and work out the details of that process whose broad foundation is given to man in the Qur'an the global manual.

The contemporary civilization, through information and communication technology is a product of knowledge and experiment, which has it bases and obligation in the sources of Islam (Qur'an and Hadith).

The prophet's declaration to knowledge brought him into the closest affinity with the modern thought. The prophet (SAW) commanded all believers to struggle for knowledge for their divine and mundane advancement.

Where he said:

"Seeking for knowledge is obligatory for every Muslim" (Hadith).

The primary manual (Qur'an), deals with genesis of education, the creations and basic nature of man and the world around him. Through the study of the Qur' an we would be able to formulate a workable integrated curriculum with a unique philosophy and technology. The principles and rules which governs man's life in this world and the next are not left to man's weak reasoning, But is regulated by God-given laws inferred from the Qur'an. (Coeasu vol ii page121). Allah (SWT) the creator of Heaven and earth said: 
"Nothing have we omitted from the Book (Qur'an)", (Qur'an, 6: 38)

Everything pertaining to this world has been explained in the Qur'an. Knowledge of the universe is not a product of man's interaction with his environment as western secular viewed, knowledge is divine, it originate from the Creator who created all creations and sent down the Qur'an as manual or guide.

Islamic education is very much unique and comprehensive by nature. Education in Islam is the most powerful instrument for progress and advancement, it aims at the total development of man. Education in Islam is basic, and a continuous process from cradle to grave. The source of all knowledge is Allah (SWT) taught our father Adam (A.S.) the nature of all things.

"And He taught Adam all the names... when Adam had informed them the names, He said did I not tell you that I know the secret of Heavens and the earth? And I know that which you disclosed and that which you hide", (Qur'an, 2: 31-32).

In the Qur'an everything in the universe has been explained and a guide given, Allah (SWT) says:

"Thus indeed have we given in this Book (Qur'an) many facets to every kind of lesson Designed for (the benefit of) mankind...", (Qur'an, 18: 58).

Islamic education is a strong foundation for building a righteous personality, who will benefit from his knowledge in both worlds. Islamic education brought about transformation to the life of people who accepted it. And equally opens ways for successful advancement in all facets of life.

\section{QUR'AN THE GLOBAL MANUAL}

Someone might asked, whether the contemporary globalization has any base in the Qur'an, forgetting the fact that, the universe is a divine creature and the Qur'an is a divine rules or guide to the entire universe for its successful operation.

Allah (SWT) is the sovereign creator and law giver of His creations. Man is merely His agent (Khalifah) and servant on His earth. Whatever a vicegerent or ambassador does, he does so as a representative, so is man on earth.

This means that only Allah (SWT) the creator has right to lay down the rules for the creatures.

Allah (SWT) said:

"Then we set you upon a rules (Shari'ah), so follow it and do not follow the whims of those Who know not", (Qur'an, 45; 18).

In the Qur'an, technology could be derived as proofs. The first piece of information (revelation) therein which alerts man about scientific technology reads;

"Read in the name of your Lord and cherisher who created...", (Qur'an, 96:

$1)$. 
This divine hint signifies to the entire mankind, the acquisition of general knowledge without limitation, technology inclusive. Muslims are venture into the pursuit of knowledge which should not be confined within the realms of Islamic education rather the acquisition should cut across all branches of available types of knowledge in all ramifications (Badmos O. Y. and salisu T. M. Correlate of Islam page 186).

Thus Muslims scholars ventured into meaningful contribution in sciences, like Ibn Rushd, who made sharp distinction between religious truth and scientific truth, he equally paved way for theological dogmatism. Ibn Sinan otherwise known in the west as "Avicenna" the prince of physicians (980-1037), and renown mathematician Muhammad Ibn Musa, the first to use decimal notation and give digits the value of position (Ibid page 187). All these scholars were not relenting their efforts to contribute their quota to the knowledge of science. Allah (SWT) grant permission for universal space exploration to those who possessed knowledge to do so. Allah (SWT) says;

"O company of Jinn and Mankind, if you are able to pass beyond the regions of the heavens and the earth, then pass. You will not pass expect by authority (from Allah)", (Qur'an. 55: 33).

in another related verse, Allah (SWT) added;

"And $\mathrm{He}$ (Allah) has subjected to you whatever is in the heaven and whatever is in the earth all from Him. Indeed in that are signs for a people who give thought", (Qur'an, 45: 13).

These verses indicates that everything in the universe is made for the benefit of man, it is left for man to make effort and initiative to acquire the requisite knowledge and technology on how to exploit these abundant bounties for his own benefit.

Striving to achieve success is part of moral obligation, Islam encourage man to strive, not to give up hope because God gives when He pleases. Deviation from moral thought of Islam is responsible for the erratic behavior of people. Consequently the society suffers with proliferation of all kinds of crimes.

The contemporary world will no doubt witness free-crime, remarkable strides in science and technology in all spheres of human life, and witness a lot of improvements all over the world, of the divine manual is properly referred and utilized. Islam is a living religion which enjoins seeking scientific and technological knowledge. Muslims are encouraged to seek for every kind of knowledge, Islam considered knowledge as a lost property of a believer, which $\mathrm{h}$ must hold wherever he found it.

The prophet's call to seek knowledge even unto China signifies that distance is no barrier to search for it. A means of reaching China and even beyond is the internet which is considered as a group of computers located all over the world connected to each other through telephone lines and satellite communication (Imam Y. O. Information and communication technology through the lenses of Arabic and Islamic studies, page 93).

\section{CONCLUSION}

Haven gone through this paper, someone might be confused, and may need clarification on the disturbing situation in the country, "Boko Haram". And likely asked "if the teaching of Islam (in Qur'an and Hadith) encouraged and mandated Muslims to seek for every kind of knowledge, then why "Boko haram?" Every sincere and knowledgeable Muslim would 
respond to this wrong assertion that 'boko haram' is not Islamic, neither motivated by the sincere Muslims. It may be either politically or materially motivated, by some politician or materialists, a mechanism of achieving their ugly political or material motives in the country.

The command to seek for knowledge in Islam does not make restrictions to religious knowledge alone, but all knowledge that could contribute to individual and societal development.

\section{Suggestions}

Leadership in the world and Nigeria in particular need justice from foundation to the running affairs of the government. Islam perceived each and every member of society as responsible who is responsible for those under him, to ensure that they live in to promote peace, which is the main teaching of Islam. A leader is expected To uphold the spirit of justice in his style of leadership, as injustice leads to the destruction of the society or nation (Muhibbuddin ed. Education Crises page 31). Obedience to the divine authority and respect for terms of covenant and treaties are all steps toward prevention of conflict in the society. Divine moral thought of the Qur'an as global manual, should not be ignore I order to have free-crime, freeconflict and peaceful global village. Application of these suggestions would help in solving the problems of the modern society.

\section{References}

[1] Adebayo R. I. (2008). Islamization of knowledge: Global development, individual effort and Institutional contribution, Kano Nigeria, IIIT.

[2] Maududi S. A. (1992). Towards understanding Islam, Saudi-Arabia International Islamic Publication House.

[3] Ali A. H. (1994). Islam and the world, Kuwait, International Islamic Book centre.

[4] Siddiqui (2008). Threatened global information, The Muslim world league journal vol. 36 , no 5.

[5] Imam M. A. (2009). Public administration and Information and communication Technology Through the lenses of Arabic and Islamic studies, Ijebu-ode, shebotimo publishers.

[6] Muhibuddin M. (2007). Education Crises in Nigeria, Arabic and Islamic perspective, Ijebu-Ode, Publishers.

[7] Badmos O. Y., Salisu T. M. (2001). Correlate of Islam, Kaduna Nigeria, Ahmadu Bello University press limited.

[8] Rashid S. K. (1987). Shari'ah, Social change and indiscipline in Nigeria, Lagos, Islamic publication.

[9] Yusuf A. (1968). Qur'an, Text and commentary, New York, Hodder limited.

[10] Kabiru Ibrahim Yankuzo, International Letters of Social and Humanistic Sciences 4 (2014) 1-8.

[11] Uloma Charity Oguzor, International Letters of Social and Humanistic Sciences 4 (2014) 97-104. 
[12] Latifat Apeke Saka, Bola Sebiomo, International Letters of Social and Humanistic Sciences 8(2) (2014) 90-98.

[13] S. A. Kazeem, K. Y. Balogun, International Letters of Social and Humanistic Sciences 8(2) (2014) 108-119.

[14] Hakeem A. Akitoye, International Letters of Social and Humanistic Sciences 14 (2014) 42-49. 